\title{
Desarrollo de jalea de yacón de reducido valor calórico: caracterización físico-química, microbiológica y sensorial
}

\author{
Development of a low calorie yacon jam: \\ physico chemical, microbiological and sensory characterization
}

\begin{abstract}
This study aimed to evaluate the physical-chemical, microbiological and sensory characteristics of four formulations of yacon jams. The following characteristics were analyzed: chemical composition, soluble solids, $\mathrm{pH}$, microbiological presence of total coliforms and salmonella at $45^{\circ} \mathrm{C}$, and presence of fungi and yeasts. The yacon jams exhibited high moisture content (> $62 \%)$ as well as high concentrations of carbohydrates (>28\%) and total dietary fiber (2.5\%), mainly fructooligosaccharides (>0.9\%). The average energy value was $124.6 \mathrm{kcal} / 100 \mathrm{~g}$. The average $\mathrm{pH}$ was 3.8 and the soluble solids measured $27.6^{\circ}$ Brix. All yacon jams complied with standard microbiological requirements and received high acceptance scores, especially the yacon jam and yacon jam with cinnamon. Yacon jam products may offer an excellent alternative to more common jams due to their lower concentrations of simple sugar, lower calorie value, increased presence of dietary fibers, and desirable sensory characteristics. Key words: yacon, jam, food fiber, fructooligosaccharides, microbiological safety, sensory analysis.
\end{abstract}

\section{INTRODUCTION}

Yacon (Smallanthus sonchifolius) is a plant native to the Andes, which was introduced in Brazil in the early 90's. In mid2000 , this root started to be significantly consumed and became popularly known as yacon potato or diabetic potato. Yacon tuberous roots are rich in fructans (fructooligosaccharides and inulin) and insoluble fiber, with potential beneficial effect on health $(1,2,3)$. The energy value of the root is considered low due to the high water content, around $90 \%$ of its fresh weight. Carbohydrate is the main component of its dry matter, about $90 \%$; while 40 to $70 \%$ is composed of fructooligosaccharides (FOS); 5 to $15 \%$ of sucrose; 5 to $15 \%$ of fructose; and less than $5 \%$ of glucose. The other components (proteins, lipids, vitamins and minerals) are found at lower amounts (4).

The FOS is completely fermented in the colon by probiotic microorganisms (5). These bacteria, mainly some species of the genera Lactobacillus and Bifidus, help improve the digestive function and relieve many digestive disturbances. The fermentation of these carbohydrates in the colon has also been related to the strengthening of the immune response, higher assimilation of calcium, reduced cholesterol and triglyceride levels and inhibition of the production of toxins that can lead to the development of colon cancer (4).

\author{
Aline Carvalho Salvador (1) \\ Maria Inês de Souza Dantas (1) \\ Christiane Mileib Vasconcelos (2) \\ Maria Cristina Dantas Vanetti (3) \\ Sônia Machado Rocha Ribeiro (1) \\ Bárbara Nery-Enes (1)Julia D Nelson (4) \\ Hércia Stampini Duarte Martino (1)
}

(1) Federal University of Viçosa, Department of Nutrition and Health, Viçosa, MG, Brazil. (2) Federal University of Viçosa, Department of Food Technology, Viçosa, MG, Brazil. (3) Federal University of Viçosa, Department of Microbiology, Viçosa, MG, Brazil. (4) Texas A\&M University, Department of Nutrition and Food Science, Texas, USA.

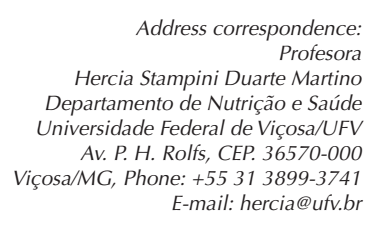

Este trabajo fue recibido el 5 de Octubre de 2011 y aceptado para ser publicado el 20 de Julio de 2012.

In addition to the functional properties, FOS also have desirable technological characteristics, since, as non-reducing sugars, they are not susceptible to the Maillard reaction. As for stability, these compounds are stable at $\mathrm{pH}$ values higher than 3 and temperatures up to $140{ }^{\circ} \mathrm{C}$. Besides, they are not degraded in most thermal processes of food industries (6).

Due to its composition, yacon self life is very short, approximately seven days. Therefore, yacon-based products have been developed to be used as ingredients of low-fat and reduced calorie preparations that provide physiological benefits to consumers (7). Jams are easily manufactured, aggregate value and allow food conservation for an extended period of time, thus playing a major role in food industry. They can become an alternative to raw or processed foods that receive the addition of yacon.

Thus, this study aimed to develop yacon jams with and without condiments and evaluate their physical-chemical and microbiological characteristics and sensory acceptability.

\section{MATERIAL AND METHODS}

Development of yacon jams

Four formulations of yacon jam were developed, with four different flavors: natural, cinnamon, nutmeg and ginger. 
The yacon used in the experiment was purchased in a grocery store in the city of Viçosa. It was washed in tap water and sanitized with $200 \mathrm{mg}$.L-1 of active chlorine for 15 minutes. Later, the yacon was husked and immersed in a solution of $0.5 \%$ sodium bisulfite ( $\mathrm{p} / \mathrm{v}$ ) for 15 minutes to prevent enzymatic browning (8). Part of the yacon was shredded (about 18\% $\mathrm{p} / \mathrm{p}$ ), and the remainder was ground in a household blender (ARNO) for the processing of the jams. Subsequently, the $\mathrm{pH}$ of both portions combined was corrected to 3.9 with citric acid $(9,10)$. Then, the mixture was heated in a nonstick pan until it reached $70^{\circ} \mathrm{C}$. As previously performed, $0.7 \% \mathrm{p} / \mathrm{p}$ pectin was homogenized in sugar to prevent the undesirable formation of lumps (11) and was added with $13.6 \% \mathrm{p} / \mathrm{p}$ sugar (12) to the yacon pulp. The jams were concentrated until reaching 28 ${ }^{\circ}$ Brix and the cinnamon bark, grated nutmeg and dried ginger powder condiments were added after cooking.

Proximal composition of the yacon jams

The proximal composition of the yacon jams was determined by the Association of Official Analytical Chemists methods (13). The results of each determination were expressed based on the average of three replicates for each sample.

The following analyses were performed: moisture content, by the gravimetric method (method 935.29); protein, by the micro-Kjeldahl method (method 991.20); lipids, by direct extraction in Soxhlet (Method 963.15); and ashes, by incineration (method 923.03).

The levels of total dietary fiber and fructooligosaccharides (FOS) were determined based on the results obtained by Vasconcelos et al. (14), who studied the proximal composition of yacon of same origin used in this work. The quantity of total dietary fiber was obtained by the sum of insoluble and soluble fibers, FOS and inulin.

The carbohydrate fraction was determined to be the remaining portion of the sample after discounting the levels of moisture, protein, lipids, ashes and total dietary fiber (15).

The caloric value of yacon jams was calculated by using the Atwater coefficients, which consider $4 \mathrm{kcal} / \mathrm{g}$ for proteins and carbohydrates, and $9 \mathrm{kcal} / \mathrm{g}$ for lipids (16).

Physical-chemical analyses of yacon jams

The determination of $\mathrm{pH}$ of the yacon jams was made according to the 017/IV method described by the Instituto Adolfo Lutz (Adolfo Lutz Institute) (17) through direct reading with a digital pH meter (Tekna T-1000, model T-1000) using a $10 \mathrm{~g}$ from each experimental unit.

Total soluble solid content (CSS) was measured directly in a bench-top ABBE refractometer at temperature of $20^{\circ} \mathrm{C}$, with results given in ${ }^{\circ}$ Brix according to the analytical standards of the Adolfo Lutz Institute (17).

The roots of yacon were weighed before and after of husked, to calculate the average yield of the jams. The jams also were weighed and it was calculated the percentage of yield in relation to the weight of the roots with husk.

Microbiological analysis of yacon jams

Following the standards established by the Resolution Number 12 of the CNNPA 1978 ANVISA (18) for jams, the microbiological analysis of total coliforms, thermotolerant coliforms $\left(45^{\circ} \mathrm{C}\right)$ and salmonella were performed, and counting of fungi and yeasts. The analyses were conducted as recommended by the Normative Instruction Number 62, of August 26, 2003, of the Ministry of Agriculture, Cattle Raising and Supply (19). Portions of $25 \mathrm{~g}$ of the product aseptically weig- hed were homogenized with $225 \mathrm{~mL}$ of $0.1 \%$ peptone water in Stomacher (B) (Seward, UK). Appropriate decimal dilutions were prepared and aliquots of these dilutions were transferred to specific medium for each group of microorganisms. Each dilution was plated in duplicate.

\section{Sensory analysis of yacon jams}

The evaluation of the sensory acceptability of the four formulations of yacon jams was performed in a supermarket in the city of Viçosa, MG.

People of both sexes participated in the analysis, after reading and signing the free consent form, in accordance with the Resolution 196/96 of the National Health Council (20). The samples were served in disposable cups of $50 \mathrm{~mL}$ identified with random three-digit codes, with lightly salted biscuits as food base.

The general acceptance of the jams was evaluated using a 9-point structured hedonic scale (21). Age group, gender and frequency of consumption of jam were investigated, besides the sensory evaluation.

The results of the sensory assessment were analyzed in a randomized block design, and the consumers were represented by blocks. The results were evaluated using the internal preference mapping technique, it based on the Principal Component Analysis, using the SAS (Statistical Analysis System), licensed for use by the Federal University of Viçosa (22).

\section{RESULTS AND DISCUSSION}

Table 1 presents the proportions of the ingredients of the formulations of the yacon jams.

Physical-chemical analyses of the yacon jams

The yacon jams presented high moisture content and reduced of proteins and lipids content and, consequently, low caloric value (table 2).

The legislation establishes the maximum moisture content of 35 to $38 \% \mathrm{p} / \mathrm{p}$ in fruit jams (20). Higher values were found for the yacon jams developed in this study, which ranged from 62.0 to $68.1 \%$. This can be explained by the high content of water in the roots, around $90 \%$ of their weight (14) and the presence of FOS in yacon jams. The chemical composition of fructooligosaccharides (FOS) includes $\mathrm{OH}$ groups available for binding, and these groups can interact with water by hydrogen bonds $(23,24)$, hindering evaporation during the process of jam concentration. The moisture content of the yacon jams prepared was comparable to those formed from yacon guava and acerola by Prati et al. (25) and the light hibiscus jam developed by Nachtigall et al. (26). However, the moisture content of these jams is outside the legally accepted range; therefore, future studies must be realized to establish methods to adjust the amount of this constituent, and, moreover, should provide recommendation for legislation regarding light jams.

Carbohydrates were the prevailing components of yacon jams, followed by total dietary fiber, which $36-40 \%$ are represented by FOS. The Decree Number 27 (27) establishes that functional foods are those that provide at least 3 grams of total dietary fiber or of FOS in solid foods, per portion of the product ready for consumption. Considering that the reference value for the portion of jam is $20 \mathrm{~g}$, according to the DRC 359 (28), the yacon jams cannot be considered source of total dietary fiber or FOS, because approximately 0,5 g of total dietary fiber and $0.2 \mathrm{~g}$ of FOS were obtained per portion of the product. However, the yacon jams can be considered products that contain functional ingredients with prebiotic activity. 
Proteins, lipids and ashes are present in small amounts in the yacon jams. This had already been expected, because the yacon pulp has low content of these components (3).

The caloric value of the yacon jams was ranged from 116.4 to $140.0 \mathrm{kcal} / 100 \mathrm{~g}$ or 23.3 to $28.0 \mathrm{kcal} /$ portion. Higher caloric values were found for fruit jams in the Table Brazilian of the Food Composition (29) (238 kcal/100g) and Table of Chemical Composition of Foods of the UNIFESP (30) (278 kcal/100g), demonstrating that the addition of yacon can reduce the caloric value of yacon jams.

The yacon jams reduced caloric value in more than $40 \%$, compared to the caloric value of the jams already mentioned, and can be considered as light or "reduced calorie" products (27). The high sweetening ability of the sugars present in yacon, mainly fructose (31), contributed to the preparation of a jam with low addition of sucrose and therefore, with low content of calories.

The average content of soluble solids was $27.6^{\circ} \mathrm{Brix}$, which is below the value recommended by law, at least $62^{\circ} \mathrm{Brix}$ for the common jam (18), due to reduced sugar composition, being considered light.

The final products presented average $\mathrm{pH}$ of 3.8. The control of $\mathrm{pH}$ in the jams affect microbial control (32) and gel formation. In jams, usually occurs gelatinization at $\mathrm{pH}$ up to 3.4. However, syneresis occurs at pH below 3.1 (11). The formulations were prepared at $\mathrm{pH} 3.8$, which provided ade- quate gelatinization. The $\mathrm{pH}$ value is also important to prevent the degradation of FOS, since they can undergo hydrolysis at values below 3.5 and thus increase the heating period during the processing of jam and reduce the content of this prebiotic component (30).

The average yield of the jams was $65 \%$, with correction factor of 1.24, suggesting that yacon is a viable alternative for the preparation of jams.

Microbiological analysis of yacon jams

All yacon jams developed were of according with recommended requirements to ensure the safety of the products ready for consumption (table 3 ).

\section{Sensory analysis of yacon jams}

The samples of jam were evaluated by 100 consumers from 13 to 60 years of age, $59 \%$ male and $56 \%$ of consumers were regular consumers of jam.

The jams of yacon, yacon with cinnamon, yacon with nutmeg and yacon with ginger were accepted by most consumers, and were ranked with the hedonic terms "I extremely liked" and "I slightly liked" by 83, 87, 82 and $83 \%$ of the consumers, respectively (table 4).

The average acceptance rating of the tested yacon jams was 6.80. This value is similar to the ratings for quince "japanese" jam (33) and pepper with acerola jam (34).

\section{TABLE 1}

Proportion of the ingredients used in the elaboration of yacon jams.

\begin{tabular}{lcccc}
\hline Ingredients (\%) & $\begin{array}{c}\text { Jam } \\
\text { Yacon }\end{array}$ & Yacon with cinnamon & Yacon with nutmeg & Yacon with ginger \\
Yacon pulp & 85.1 & 84.4 & 85.0 & 84.8 \\
Sugar & 13.6 & 13.5 & 13.6 & 13.6 \\
Pectin & 0.7 & 0.7 & 0.7 & 0.7 \\
Sodium bisulfite & 0.4 & 0.4 & 0.4 & 0.4 \\
Citric acid & 0.2 & 0.2 & 0.2 & 0.2 \\
Condiment & 0 & 0.8 & 0.1 & 0.3 \\
\hline
\end{tabular}

TABLE 2

Average values of the proximal composition and caloric value of yacon jams.

\begin{tabular}{|c|c|c|c|c|}
\hline $\begin{array}{l}\text { Components } \\
\text { g.100g-1 }\end{array}$ & Yacon & Yacon with cinnamon & Yacon with nutmeg & Yacon with ginger \\
\hline Humidity & 62.0 & 66.5 & 68.1 & 66.1 \\
\hline Carbohydrate & 34.7 & 30.4 & 28.7 & 30.6 \\
\hline *Total dietary fiber & 2.5 & 2.5 & 2.5 & 2.5 \\
\hline${ }^{*} \mathrm{FOS}$ & 1.0 & 0.9 & 1.0 & 0.9 \\
\hline Protein & 0.4 & 0.3 & 0.4 & 0.4 \\
\hline *Lipids & 0.0 & 0.0 & 0.0 & 0.0 \\
\hline Ashes & 0.4 & 0.3 & 0.3 & 0.4 \\
\hline Caloric value ${ }^{* *}$ & 140.0 & 122.8 & 116.4 & 124.0 \\
\hline
\end{tabular}

${ }^{*}$ Calculated according to the concentration in the yacon pulp (Vasconcelos et al., 2010).

** Energetic value (kcal/100 g) calculated based on the results for carbohydrates, proteins and lipids. 
The Internal Preference Mapping analysis (Figure 1) was performed with the data obtained in the acceptance test of the four formulations.

The first Principal Component (PC) explained $42.68 \%$ and the second, $33.70 \%$, totaling $76.38 \%$ of the variance among the samples, regarding their acceptance.

The spatial separation of the samples of yacon jams suggested the existence of four distinct groups, according to their acceptance (figure 1). In figure 1, each point represented the correlations among the data from consumer acceptance and the first two principal components.

The consumers near to the center of the graph were not correlated with any of the two main components and contributed little to the discrimination of samples, i.e., these consumers demonstrated similar acceptance of the yacon jams. This group was formed by a small number of consumers. On the other hand, consumers correlated with at least one of the components considered some difference in the acceptance of the samples. For most consumers, there was a positive correlation with the first principal component, indicating that they assigned higher grades for samples of yacon jams without any condiment and that with cinnamon.

The yacon jam with ginger was the least accepted. It was in the second quadrant, where there was a smaller group of consumers correlated with this sample (Figure 1). However, its acceptance still presented high scores.

\section{CONCLUSION}

The yacon jams presented reduced caloric value and can be considered light products, without the addition of dietary sweeteners, tough. Besides, the components of the jams, including dietary fiber, mainly fructooligosaccharides, are considered prebiotic.

All the yacon jams developed were well accepted, mainly natural yacon and yacon with cinnamon. They are a viable yacon-based product, aimed at expanding the consumption of yacon and obtaining its benefits.

These characteristics suggest that yacon jams, with or without condiments, can be an excellent alternative to replace traditional jams, due to their lower levels of simple sugars, reduced caloric value, addition of functional components and sensory characteristics which are pleasant for consumers.

\section{RESUMEN}

Este estudio tuvo como objetivo evaluar las características físico-químicas, microbiológicas y sensoriales de cuatro formulaciones de mermeladas de yacón. Las características analizadas fueron: composición química, contenido de sólidos solubles, $\mathrm{pH}$, presencia microbiológica de coliformes totales, coliformes y salmonella a $45^{\circ} \mathrm{C}$, y la presencia de hongos y levaduras. Los atascos de yacón mostraron alto contenido de humedad (> 62\%), así como altas concentraciones de hidratos de carbono (> 28\%) y fibra dietética total $(2,5 \%)$, principal-

\section{TABLE 3}

Quantity of total coliforms, coliforms at $45^{\circ} \mathrm{C}$, Salmonella and counting of fungi and yeasts present in yacon jams.

\begin{tabular}{|c|c|c|c|c|}
\hline Jam & $\begin{array}{l}{ }^{*} \text { Total coliforms } \\
\text { MPN/g }\end{array}$ & $\begin{array}{c}{ }^{*} \text { Coliforms at } 45^{\circ} \mathrm{C} \\
\mathrm{NMP} / \mathrm{g}\end{array}$ & $\begin{array}{l}{ }^{*} \text { Counting of fungi } \\
\text { and yeasts CFU/g }\end{array}$ & *Salmonella \\
\hline Yacon & $<3$ & $<3$ & $<10^{2}$ & Absent in $25 \mathrm{~g}$ \\
\hline Yacon with cinnamon & $<3$ & $<3$ & $<10^{2}$ & Absent in $25 \mathrm{~g}$ \\
\hline Yacon with nutmeg & $<3$ & $<3$ & $<10^{2}$ & Absent in $25 \mathrm{~g}$ \\
\hline Yacon with ginger & $<3$ & $<3$ & $<10^{2}$ & Absent in $25 \mathrm{~g}$ \\
\hline
\end{tabular}

MPN: Most Probable Number; CFU: Colony-forming unit

*average of three replications.

\section{TABLE 4}

Frequencies of the scores attributed to the four samples of jam, for each hedonic term.

\begin{tabular}{|c|c|c|c|c|c|}
\hline Hedonic Terms & Scores & Yacon & $\begin{array}{c}\text { Jams } \\
\text { Yacon with cinnamon }\end{array}$ & Yacon with nutmeg & Yacon with ginger \\
\hline I extremely liked & 9 & 4 & 14 & 11 & 9 \\
\hline I very much liked & 8 & 35 & 38 & 21 & 24 \\
\hline I moderately liked & 7 & 30 & 23 & 32 & 25 \\
\hline I slightly liked & 6 & 14 & 12 & 18 & 25 \\
\hline Indifferent & 5 & 7 & 5 & 5 & 5 \\
\hline I slightly disliked & 4 & 8 & 3 & 7 & 6 \\
\hline I moderately disliked & 3 & 0 & 2 & 3 & 3 \\
\hline I very much disliked & 2 & 2 & 3 & 2 & 3 \\
\hline I extremely disliked & 1 & 0 & 0 & 1 & 0 \\
\hline Average & & 6.81 & 7.12 & 6.66 & 6.62 \\
\hline
\end{tabular}


mente fructooligosacáridos (>0,9\%). El valor energético promedio fue de $124,6 \mathrm{kcal} / 100 \mathrm{~g}$. El $\mathrm{pH}$ promedio fue de $3,8 \mathrm{y}$ los sólidos solubles mide $27,6^{\circ}$ Brix. Todas las mermeladas de yacón cumplido con los requisitos microbiológicos estándar y recibió altos puntajes de aceptación, en especial la mermelada de yacón y mermelada de yacón con canela. Productos de mermelada de yacón pueden ofrecer una excelente alternativa a los atascos más comunes debido a sus concentraciones más bajas de azúcar simple, un valor más bajo de calorías, el aumento de la presencia de fibras dietéticas y las características sensoriales deseadas.

Palabras clave: yacón, mermelada, fibra alimentaria, los fructooligosacáridos, la seguridad microbiológica, análisis sensorial.

\section{REFERENCES}

1. Hermann, M.; Freire, I. \& Pazos, C. 1998. Compositional diversity of the yacon storage root. In: Impact on a changing world. CIP Program Report. Lima: Centro Internacional de La Papa. P 425-32.

2. Silva, E.B.; Cândido, L.M.B.; Sabino, J.; Freitas, R.J.S. \& Stertz, S.C. Composição química da raiz e das folhas desidratadas do yacon. Revista Brasileira de Plantas Medicinais 2004. 6(3), 48-52.

3. Santana, I. \& Cardoso, M.H. Raiz tuberosa de yacon (Smallanthus sonchifolius): potencialidade de cultivo, aspectos tecnológicos e nutricionais. Ciência Rural 2008; 38(3), 898-905.
4. Manrique, I.; Párraga, A. \& Hermann, M. Yacon syrup: Principles and processing. Series: Conservación y uso de la biodiversidad de raíces y tubérculos andinos: Una década de investigación para el desarrollo (1993-2003). n. 8B. International Potato Center, Universidad Nacional Daniel Alcides Carrión, Erbacher Foundation, Swiss Agency for Development and Cooperation. Lima, Peru. 2005.

5. Pedreschi, R.; Campos, D.; Noratto, G.; Chirinos, R. \& Cisneros-Zevallos, L. 2003. Andean Yacon Root (Smallanthus sonchifolius Poepp. Endl) Fructooligosaccharides as a Potential Novel Source of Prebiotics. J Agricul Food Chem 51(18), 5278-84.

6. Mussatto, S. I. \& Mancilha, I. M. 2007. Non-digestible oligosaccharides: A review. Carbohydrate Polymers 68(3), 587-97.

7. Rolim, P.M.; Salgado, S.M.; Padilha, V.M.; Livera, A.V.S.; Guerra, N.B. \& Andrade, S.A.C. Análise de componentes principais de pães de forma formulados com farinha de yacon (Smallanthus sonchifolius (Poepp.) H. Rob.). Rev Ceres 2010. 57(1), 12-7.

8. Araújo, J.M.A. Escurecimento Enzimático. In: J.M.A. Araújo, Química de Alimentos: teoria e prática. 4 ed. Cap.10. Viçosa: UFV. 2008.

9. Lago, E.S.; Gomes, E. \& Silva, R. 2006. Produção de geléia de jambolão (Syzygium cumini Lamarck): processamento, parâmetros físico - químicos e avaliação sensorial. Ciência Tecnol Alimentos 26(4), 847-52.

10. Yuyama, L.K.O.; Pantoja, L.; Maeda, R.N.; Aguiar, J.P.L.

\section{FIGURE 1}

Correlations among the data of the acceptance of each consumer and the two first principal components and dispersion of the samples of yacon jam related to acceptance.

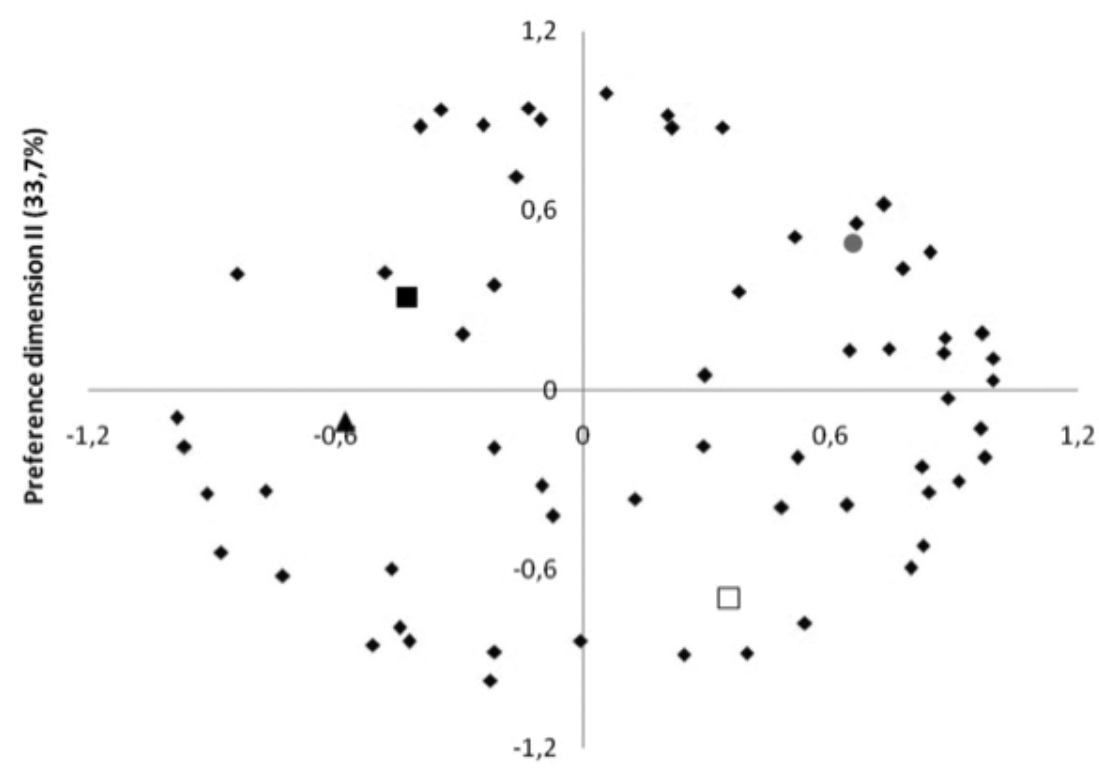

Preference dimension $\mathrm{I}(\mathbf{4 2 , 6 8 \% )}$

$\square$ Yacon Yacon with cinnamon $\quad \boldsymbol{\Delta}$ Yacon with nutmeg $\quad \mathbf{a}$ Yacon with ginger 
\& Silva, S.B. Desenvolvimento e aceitabilidade de geléia dietética de cubiu (Solanum sessiliflorum Dunal). Ciência Tecnol Alimentos. 2008. 28(4), 929-34.

11. CETEC - Fundação Centro Tecnológico de Minas Gerais. Dossiê Técnico - Fabricação de geléias. Recuperado em 20 de abril, 2011, de http://www.respostatecnica.org. br. 2007.

12. Machado, E.S.; Fonseca, A.A.O.; Hansen, D.S.; Santos, D.B. \& Silva Júnior, J.J. Produção de Geléia Mista de Umbu-cajá e Acerola com Alto Teor de Vitamina C. In: XX Congresso Brasileiro de Fruticultura e 54th Annual Meeting of the Interamerican Society for Tropical Horticulture. Vitória: XX Congresso Brasileiro de Fruticultura, Vitória/ES. 2008.

13. AOAC Association of Official Analytical Chemists. Official Methods of Analysis of the Association of Official Analytical Chemists. 17 ed. Washington. 2002.

14. Vasconcelos, C.M.; Silva, C.O.; Teixeira, L.J.Q.; Chaves, J.B.P. \& Martino, H.S.D. Determinação da fração da fibra alimentar solúvel em raiz e farinha de yacon (Smallanthus sonchifolius) pelo método enzimático-gravimétrico e por cromatografia líquida de alta eficiência. Rev Instituto Adolfo Lutz 2010. 69(2), 188-93.

15. Brasil. Resolução $n^{\circ} 40$ de 21 de março de 2001 da Agência Nacional de Vigilância Sanitária (22 de março). Regulamento Técnico para rotulagem nutricional obrigatória de alimentos e bebidas enlatadas. Diário Oficial [da] União, Brasília, DF: Poder executivo. 2001.

16. Watt, B. \& Mirrill, A.L. Composition of foods: raw, processed, prepared. Washington: Consumer and Food Economics Research Divisions/Agricultural Research Service. (Agriculture Handbooke, 8). 1963.

17. Instituto Adolfo Lutz. Normas Analíticas do Instituto Adolfo Lutz, In: Métodos químicos e físicos para análise de alimentos, 3. ed. Vol. 1. São Paulo: IMESP. 1985.

18. Brasil. Resolução Normativa n. 12/78 da Câmara Técnica de Alimentos (01 de fevereiro). Diário Oficial [da] República Federativa do Brasil, Brasília, DF: Conselho Nacional de Saúde. 1978,

19. Brasil. Instrução Normativa n. 62 (18 de setembro). Oficializa os Métodos Analíticos Oficiais para Análises Microbiológicas para Controle de Produtos de Origem Animal e Água. Diário Oficial [da] União, Brasília, DF, Seção 1, p. 14. 26 de agosto de 2003.

20. Brasil. Resolução 196/96 do Conselho Nacional de Saúde/ MS (1996, 10 de outubro). Diretrizes e Normas Regulamentadoras de Pesquisa envolvendo seres humanos. Diário Oficial [da] União, Brasília, DF: Ministério da Saúde. Recuperado em: de http://dtr2004.saude.gov.br/susdeaz Vegislacao/legislacao php10 de junho, 2011,

21. Stone, H. \& Sidel, J.L. Sensory Evaluation Practices. 2 ed. California: Academic Press, Redwood City. 1993.
22. SAS Statistical Analysis System. Versão 8.0. The SAS Institute, Cary, N.C. 1999.

23. Roberfroid, M.B. 1993. Dietary fiber, inulin and oligofructose: a review comparing their physiological effects. CRC-Critical Reviews Food Sci Nutr 33(2), 103-48.

24. Silva, R.F. Use of inulin as a natural texture modifier. Cereal Foods World 41(10), 1996; 792-4.

25. Prati, P.; Berbari, S.A.G.; Pacheco, M.T.B.; Silva, M.G. \& Nacazume, N. Estabilidade dos componentes funcionais de geléia de yacon, goiaba e acerola, sem adição de açúcares. Brazilian Food Technol 2009; 12(4), 285-94.

26. Nachtigall, A.M.; Zambiazi, R.C. \& Carvalho, D.S. Geléia light de hibisco: características físicas e químicas. Alimentos e Nutrição 2004;15(2), 155-61.

27. Brasil. Portaria $n^{\circ} 27$, de 13 de janeiro de 1998 da Agência Nacional de Vigilância Sanitária (16 de janeiro). Aprova o Regulamento Técnico referente à Informação Nutricional Complementar. Diário Oficial [da] União, Brasília, DF: Poder Executivo. 1998.

28. Brasil. RDC no 359 de 23 de dezembro de 2003 (2003, 26 de dezembro). Regulamento Técnico de Porções de Alimentos Embalados para Fins de Rotulagem Nutricional. Brasília, DF.

29. Tabela brasileira de composição de alimentos/NEPA. 2011. 4 ed. Campinas: NEPAUNICAMP. Recuperado em 05 de junho, 2011, de http://www.unicamp.br/ nepa/taco/contar/taco_4_edicao_ampliada_e_revisada. pdf?arquivo=taco_4_versao_ampliada_e_revisada.pd)

30. Tabela de Composição Química dos alimentos. Departamento de Informática em Saúde. Universidade Federal de São Paulo - UNIFESP. Ministério da Educação. Recuperado em 05 de junho, 2011, de http://www.unifesp.br/dis/ servicos/nutri/.

31. Mahan, L.K. \& Escott-Stump, S. In Krause. Alimentos, nutrição e dietoterapia 11 ed. Cap. 10 e 17. São Paulo: Ed Roca. 2005

32. Andrade, N.J.; Akutsu, C.K.; Antunes, V.C.; Mello, C.A. \& Silva, C.A.S. Controle de doenças de origem alimentar no processamento de alimentos. In: N.J. Andrade, C.K. Akutsu, V.C. Antunes, C.A. Mello, C.A.S. Silva, Higiene na indústria de alimentos: avaliação e controle da adesão e formação de biofilmes bacterianos. 1 ed. Cap. 10. São Paulo: Ed. Varela. 2008.

33. Pereira, G.G.; Alvarenga, A.A.; Abrahão, E.; Pinheiro, A.C.M.; Oliveira, A.F. \& Pio, R. Avaliação sensorial de geleia de marmelo 'Japonês' em diferentes concentrações de sólidos solúveis totais. Brazilian J Food Technol 2011, 14(3), 226-31.

34. Araújo, E.R.; Silva, P.K.; Rêgo, E.R.; Bairral, M.A.A; Santos, R.M.C.; Sapucay, M.J.; Farias, G.A. \& Rêgo, M.M. Análise sensorial e de aceitação comercial de geléia de pimenta com acerola. Horticultura Brasil 2009; 27, S1545-S50. 